\title{
Additional Factors in Chronic Bronchitis
}

\author{
K. J. CULLEN, ${ }^{*}$ M.D., M.R.C.P.ED. ; JANET ELDER, $†$ M.B., B.S., M.R.C.P.ED. ; A. R. ADAMS, $\ddagger$ M.B., CH.B., M.R.C.P.ED.
}

\author{
N. S. STENHOUSE, $\ddagger$ M.SC.
}

\begin{abstract}
Summary: A review of persons with chronic bronchitis $\checkmark$ and controls without bronchitis showed several irritants around the home that aggravated cough, such as house dust, flowers and grasses, smoke, strong fumes, hair spray, insecticide, and soap powders. Most subjects with bronchitis were affected by exposure to one or more of these irritants for at least once a day for three months of the year or more. Out of 163 subjects with chronic bronchitis only six non-smokers were free of factors associated with pulmonary irritation. This evidence from non-smokers not exposed to air pollution adds further strength to the hypothesis that daily phlegm is caused by persistent inhalation of irritants.
\end{abstract}

\section{Introduction}

Factors suspected of perpetuating cough or phlegm production can be investigated with advantage in rural areas relatively free from respiratory risks. An investigation of smoking habits and exposure to various pulmonary irritants was therefore undertaken in Busselton, Western Australia. In particular, further data were sought from the non-smokers not exposed to air pollution.

\section{Methods}

In September 1968163 of the 178 Busselton subjects under 70 years who had had chronic bronchitis in 1966 and 101 controls without bronchitis were recalled for investigation. A modified M.R.C. questionary (Cullen et al., 1968) was used, together with additional questions about a history of hives, sinusitis, postnasal drip, and a history of asthma or hay-fever in their relatives. They were asked, "Do any of the following aggravate your cough-house dust, flowers or grasses, alcohol, smoke, strong fumes, hair spray, insecticides, soap powders, exertion, change in temperature, anything else?" They were also asked if these factors aggravated their cough every day, daily for three months at certain times in the year, once to three times a week, once a month, or less than once a month. Non-smokers were asked why they did not smoke, ex-smokers why they had given up smoking, and smokers why they continued to smoke. Chests were auscultated for rhonchi and crepitations. Chest $x$-ray films, forced expiratory volume (1 second), and forced vital capacity were ascertained.

Control subjects ( 50 men, 51 women) had neither cough nor phlegm, so that the questions put to them concerning aggravation of cough started with "Do any of the following make you cough?" The age distribution of all subjects is given in Table I. Their mean ages were as follows: male bronchitics

* General Practitinner, Georgiana Molloy Centre, Busselton, Western

Australia.
† Physician, Thoracic Unit, Sir Charles Gairdner Hospital, Perth, Western Australia

‡ Raine Foundation Medical Statistics Unit, University of Western Australia, Perth.
TABLE I.-Age Distribution of Bronchitics and Controls: Busselton, 1966

\begin{tabular}{|c|c|c|c|c|c|c|}
\hline & $20-29$ & $30-39$ & $40-49$ & $50-59$ & $60-69$ & Total \\
\hline $\begin{array}{l}\text { Males: } \\
\text { Chronic bronchitics } \\
\text { Controls }\end{array}$ & $\begin{array}{l}7 \\
3\end{array}$ & $\begin{array}{r}19 \\
9\end{array}$ & $\begin{array}{l}25 \\
11\end{array}$ & $\begin{array}{l}32 \\
15\end{array}$ & $\begin{array}{l}33 \\
12\end{array}$ & $\begin{array}{r}116 \\
50\end{array}$ \\
\hline $\begin{array}{l}\text { Females: } \\
\text { Chronic bronchitics } \\
\text { Controls }\end{array}$ & $\begin{array}{l}5 \\
5\end{array}$ & $\begin{array}{l}6 \\
6\end{array}$ & $\begin{array}{l}13 \\
15\end{array}$ & $\begin{array}{l}16 \\
18\end{array}$ & $\begin{array}{l}7 \\
7\end{array}$ & $\begin{array}{l}47 \\
51\end{array}$ \\
\hline
\end{tabular}

49.9, controls 50.6; female bronchitics $47 \cdot 2$, controls $47 \cdot 1$. Both bronchitic and control subjects were derived from a survey which included $91 \%$ of the total population of Busselton, Western Australia, in November 1966.

\section{Results}

Grades of Phlegm in 1966 and 1968.-Of the 163 subjects with chronic bronchitis in November 1966, 11 out of 50 nonsmokers or ex-smokers no longer had daily phlegm in September 1968, compared with 10 out of 113 smokers $(\mathrm{P}<0.05)$.

Factors Associated with Chronic Bronchitis.-More people with chronic bronchitis than controls reported a history of sinusitis (47 bronchitic men and 11 controls, $P<0.05 ; 29$ bronchitic women and 12 controls, $P<0.001)$ and postnasal drip ( 60 bronchitic men and 3 controls, $\mathrm{P}<0.001 ; 26$ bronchitic women and 7 controls, $\mathrm{P}<0.001$ ).

Factors Aggravating Cough.-Table II summarizes the factors reported to aggravate cough. In men with bronchitis the order of frequency was smoke $(\mathrm{P}<0.001)$, exertion

TABLE II.-Factors Aggravating Cough in Chronic Bronchitis, Busselton, 1968

\begin{tabular}{|c|c|c|c|c|c|c|}
\hline \multirow{2}{*}{$\begin{array}{c}\text { Factor } \\
\text { Aggravating } \\
\text { Cough }\end{array}$} & \multicolumn{2}{|c|}{ Males } & & \multicolumn{2}{|c|}{ Females } & \multirow[b]{2}{*}{$x^{2}$} \\
\hline & $\begin{array}{c}\text { Chronic } \\
\text { Bronchitics } \\
\text { (116) }\end{array}$ & $\begin{array}{c}\text { Controls } \\
(50)\end{array}$ & $x^{2}$ & $\begin{array}{c}\text { Chronic } \\
\text { Bronchitics } \\
(47)\end{array}$ & $\begin{array}{c}\text { Controls } \\
(51)\end{array}$ & \\
\hline $\begin{array}{l}\text { House Dust } \\
\text { Flowers and grasses } \\
\text { Smoke } \\
\text { Insecticide } \\
\text { Strong fumes } \\
\text { Soap powder }\end{array}$ & $\begin{array}{l}20(17) \\
20(17) \\
83(72) \\
23(20) \\
38(33) \\
12(10)\end{array}$ & $\begin{array}{r}2(4) \\
2(4) \\
14(28) \\
5(10) \\
10(20) \\
0\end{array}$ & $\begin{array}{r}4 \\
4 \\
26 \\
\text { N.S. } \\
\text { N.S. } \\
\mathbf{4}\end{array}$ & $\begin{array}{l}15(32) \\
17(36) \\
28(60) \\
23(49) \\
20(43) \\
11(23)\end{array}$ & $\begin{array}{r}2(4) \\
2(4) \\
4(8) \\
7(14) \\
11(22) \\
5(10)\end{array}$ & $\begin{array}{r}11 \\
14 \\
27 \\
13 \\
4 \\
\text { N.S. }\end{array}$ \\
\hline $\begin{array}{l}\text { erature } \\
\text { Exertion } \\
\text { Other } \\
\text { Alcohol }\end{array}$ & $\begin{array}{l}33(28) \\
49(42) \\
19(16) \\
10(9)\end{array}$ & $\begin{array}{ll}3 & (6) \\
6 & (12) \\
1 & (2) \\
0\end{array}$ & $\begin{array}{r}9 \\
13 \\
6 \\
\text { N.S. }\end{array}$ & $\begin{array}{r}15(32) \\
23(49) \\
6(13) \\
1 \quad(2)\end{array}$ & $\begin{array}{l}1 \\
5(2) \\
0 \\
0\end{array}$ & $\begin{array}{r}14 \\
16 \\
5 \\
\text { N.S. }\end{array}$ \\
\hline
\end{tabular}

N.S. $=$ Not significant

Percentages are given in parentheses.

$(\mathrm{P}<0.001)$, temperature changes $(\mathrm{P}<0.001)$, house dust $(P<0.05)$, flowers and grasses $(P<0.05)$, miscellaneous $(P<0.05)$, and soap powders $(P<0.05)$. In women the order of frequency was smoke $(P<0.001)$, insecticide $(P<0.001)$, exertion $(P<0.001)$, strong fumes $(P<0.05)$, flowers and grasses 
$(\mathrm{P}<0.001)$, change in temperature $(\mathrm{P}<0.001)$, and miscellaneous $(P<0.05)$. Women were more likely than men to have cough aggravated by insecticide $(P<0.001)$ and flowers and grasses $(P<0.05)$. Table III shows that more non-smoking

TABle III.-Factors Aggravating Cough in Chronic Bronchitis According to Smoking: Busselton, 1968

\begin{tabular}{l|c|c|c|c|c}
\hline & $\begin{array}{c}\text { Non- } \\
\text { smoking } \\
\text { Bronchitics } \\
(28) \\
\text { A }\end{array}$ & $\begin{array}{c}\text { Controls } \\
(101) \\
\text { B }\end{array}$ & $\begin{array}{c}\chi^{2} \\
\text { Differences } \\
\text { between } \\
\text { A and B }\end{array}$ & $\begin{array}{c}\text { Smoking and } \\
\text { Ex-smoking } \\
\text { Bronchitics } \\
(135) \\
\text { C }\end{array}$ & $\begin{array}{c}\chi^{2} \\
\text { Differences } \\
\text { between } \\
\text { A and C }\end{array}$ \\
\hline $\begin{array}{l}\text { House dust } \\
\text { Flowers and Grasses }\end{array}$ & $12(43)$ & $4(4)$ & 27 & $23(17)$ & 8 \\
Smoke & $12(43)$ & $48(4)$ & 23 & $26(19)$ & 4 \\
Strong fumes & $14(50)$ & $20(18)$ & 6 & $99(73)$ & 9 \\
Hair spray & $7(25)$ & $5(5)$ & 9 & $44(33)$ & N.S. \\
Insecticide & $14(50)$ & $12(12)$ & 18 & $5(4)$ & 12 \\
Soap powder & $7(25)$ & $5(5)$ & 8 & $16(12)$ & N.S. \\
\hline
\end{tabular}

N.S. $=$ Not significant

Percentages are given in parentheses.

bronchitics than controls reported aggravation of cough by hair sprays $(P<0.01)$. In those with bronchitis, more nonsmokers than a combined group of smokers/ex-smokers reported aggravation of cough by house dust $(\mathrm{P}<0.01)$, flowers and grasses $(P<0.05)$, hair sprays $(P<0.001)$, and insecticide $(P<0.01)$. More of the combined group of smokers/exsmokers than non-smokers reported aggravation of cough by smoke $(P<0.01)$. With regard to the total number of inhaled pulmonary irritants (excluding exertion and change in temperature) the average number of factors aggravating cough per individual was 2.8 for non-smokers, 1.8 for combined smokers/ex-smokers, and $\mathbf{0 . 7}$ for controls.

Frequency of Factors Aggravating Cough.-The frequency in smoking categories with which cough was aggravated by all factors other than exertion and changes in temperature is given in Table IV. In addition one or more factors aggravated cough daily for at least three months of the year in 15 of the 28 non-smokers, in 97 of the 135 smokers/ex-smokers, and in 11 of the 101 controls $(P<0.001)$. Excluding the factors smoke, exertion and temperature changes, 10 of the 28 nonsmoke, exertion, and temperature changes, 10 of the 28 nonmore of the remaining factors aggravating cough daily for at least three months, compared with 2 of the 101 controls $(\mathrm{P}<0.001)$.

Attitudes to Smoking.-Reasons given by the 28 nonsmokers for not smoking included that the habit was a filthy one (20), was not enjoyable (20), had never been tried (8), and the subject wanted to keep fit (8). Reasons advanced by 22 ex-smokers for stopping included respiratory infections (12), doctor's advice (5), fear of lung cancer (4), illness (4), and other (10). The reasons why 113 smokers kept smoking were: unable to stop or do without (65), no desire to stop (57), afraid of weight gain (26), and other (36). Doctors had advised 56 of the 113 smokers to stop smoking.

\section{Discussion}

In 1966 the prevalence of chronic bronchitis in 1,461 Busselton non-smokers (1.9\% for men and $2.3 \%$ for women) showed no increase with advancing age (Cullen et al., 1968). By 1968 more non-smokers and ex-smokers than smokers had lost their daily phlegm-an early confirmation of the prevalence findings that non-smokers not exposed to air pollution eventually recover from chronic bronchitis. Despite the admission from most smokers that smoke aggravated their cough, few were giving up the habit. Less than half of the smokers had received a doctor's warning against smoking-a reflection of the area's doctors' efforts to prevent bronchitis.

Why should non-smokers suffer from chronic bronchitis if they have dust-free jobs in an environment such as Busselton? Despite similar smoking habits, why do some smokers and not others have daily phlegm? A possible answer to both questions is provided by the variety of irritants around the home that aggravated cough (Table II). In each smoking category smoke (including that from tobacco) was the commonest single factor causing daily aggravation of cough (65 out of 163 with bronchitis). This favours a higher prevalence of bronchitis being found wherever there is inadequate ventilation of fuel-burning fires-a matter perhaps easier to alleviate than tobacco smoking in the home. Excluding smoke, other factors appeared more important in non-smokers than in smokers/ex-smokers (Table III), indicating the potential hazards

TABLE IV.-Frequency of Factors* Aggravating Cough in Chronic Bronchitics and Controls: Busselton, 1968

\begin{tabular}{|c|c|c|c|c|c|c|}
\hline Category & $\begin{array}{l}\text { Total } \\
\text { Factors }\end{array}$ & Daily & $\begin{array}{c}\text { Daily for } \\
\text { at least } \\
3 \text { Months }\end{array}$ & $\begin{array}{l}\text { 1-3 times } \\
\text { a Week }\end{array}$ & $\begin{array}{l}\text { Once a } \\
\text { Month }\end{array}$ & $\begin{array}{l}\text { Less than } \\
\text { once a } \\
\text { Month }\end{array}$ \\
\hline $\begin{array}{l}\text { Non-Smoking bron- } \\
\text { chitics } \\
\text { Smoking and ex-smoking }\end{array}$ & 77 & $20(26)$ & $6(8)$ & $19(25)$ & $14(18)$ & $18(23)$ \\
\hline $\begin{array}{l}\text { bronchitics } \\
\text { Non-bronchitic controls }\end{array}$ & $\begin{array}{r}245 \\
68\end{array}$ & $\begin{array}{r}111(45) \\
9(14)\end{array}$ & $\begin{aligned} 31(13) \\
2(3)\end{aligned}$ & $\begin{array}{l}31(13) \\
10(15)\end{array}$ & $\begin{array}{l}20(8) \\
10(15)\end{array}$ & $\begin{array}{l}50(20) \\
37(54)\end{array}$ \\
\hline
\end{tabular}

*Excluding exertion and change in temperature.

Percentages are given in parentheses.

of occupations involving hair sprays, insecticides, and petroleum fumes. No evidence was available to show causal relationship between phlegm and daily contact with these factors. Nevertheless, the data from the non-smokers with bronchitis favoured the hypothesis that daily phlegm is due to the inhalation of persistent irritants.

Of the 28 non-smokers, 15 had daily aggravation of cough for at least three months of the year from one or more of the factors around the home. Of the remaining 13 non-smokers, seven were exposed to dust in their occupations, two had both sinusitis and postnasal drip, one had sinusitis, and another had asthma. Of the total 163 subjects with chronic bronchitis, only six had no history of daily reaction with or exposure to pulmonary irritants. Longitudinal studies will reveal the nonsmokers who learn to avoid irritant factors and those who lose their daily phlegm. This should help to assess the importance of the home environment in chronic bronchitis.

We gratefully acknowledge the financial assistance of the Raine Foundation. We also thank the Public Health Department, Mr. T. Noonan of the Busselton District Hospital, Dr. Colin Matthews for assistance with interviews, and the Busselton voluntary helpers, especially Mr. D. B. Pinnock, sen.

Requests for reprints to Dr. K. J. Cullen, Department of Medicine, University of Western Australia, Perth, W.A.

\section{REFERENCE}

Cullen, K. J., Stenhouse, N.S., Welborn, T. A., McCall, M. G., and Curnow, D. H. (1968). Lancet, 2, 657 